\title{
Death of a few celebrated truths and others still worth re-stating
}

\section{Maurice Godelier}

\section{Q OpenEdition \\ 1 Journals}

\section{Electronic version}

URL: http://journals.openedition.org/jso/871

DOI: $10.4000 /$ jso.871

ISSN: $1760-7256$

\section{Publisher}

Société des océanistes

\section{Printed version}

Date of publication: 1 December 2007

Number of pages: 181-192

ISBN: 978-2-85430-010-9

ISSN: 0300-953x

\section{Electronic reference}

Maurice Godelier, " Death of a few celebrated truths and others still worth re-stating », Journal de la Société des Océanistes [Online], 125 | Année 2007-2, Online since 01 December 2010, connection on 23 April 2019. URL : http://journals.openedition.org/jso/871 ; DOI : 10.4000/jso.871

(C) Tous droits réservés 


\section{Death of a few celebrated truths and others still worth re-stating 1}

by

Maurice GODELIER*

\begin{abstract}
Firth produced a great work but he was also a great man. Having set out to study political economics in New Zealand, Raymond Firth encountered Malinowski and decided to become an anthropologist. The fieldwork and books followed, on subjects ranging from Polynesia to the housing projects of London. Some of these were masterpiece, like We, The Tikopia (1936) or The Work of the Gods in Tikopia (1940). An immensely rich store of ethnographic material, laid out precisely and clearly but also theoretical works on key areas: religion, symbols, etc. in which, well before the postmodernists, Firth voiced his skepticism about "grand theories», Marxism, Structuralism, etc. The author of the lecture next asks the question: Why should we celebrate a great anthropologist if anthropology is nothing more than a bunch of narrative fictions written by Europeans with the complicity of their native informants (Marcus) and is therefore a dying literary genre? He replies that there are two ways of deconstructing a discipline: one that leads to its dissolution and the other that leads to its reconstruction on a more rigorous and analytically more effective basis. The author opts for the second way and analyses several issues: the distinction between the imaginary and the symbolic, and their respective roles in producing social relations. He then seeks to identify among all social relations, those that have the capacity to bind a certain number of human groups into a Whole that endows them with an overarching shared identity and makes them into a society. He shows that the only relations that have this capacity are political-religious relations, not kinship relations or economic relations. Lastly, considering the trade of the anthropologist, he sets out a number of conditions that must be fulfilled in
\end{abstract}

\section{RÉSUMÉ}

Firth, une grande auvre mais aussi un grand homme. Ayant commencé en Nouvelle-Zélande des études d'économie politique, Firth rencontre Malinowski et choisit de devenir anthropologue. De la Polynésie à la banlieue de Londres en passant par la Malaisie, les terrains et les livres se succèdent et s'accumulent parmi lesquels des chefs-d'euvre We, The Tikopia (1936) ou The Work of the Gods in Tikopia (1940). Un matériel ethnographique d'une immense richesse exposé avec précision et clarté mais aussi des ouvrages théoriques sur des domaines clés : la religion, les symboles etc. où Firth manifestait bien avant les critiques des post-modernistes un scepticisme vis-à-vis des "grandes théories》, le marxisme, le structuralisme, etc.

L'auteur pose alors la question : Pourquoi célébrer un grand anthropologue si l'anthropologie n'est qu'une suite de récits-fictions écrits par des Européens " avec la complicité de leurs informateurs-indigènes " (Marcus) et est donc un genre littéraire en voie de disparition? Il répond en montrant qu'il y a deux façons de déconstruire une discipline, l'une qui aboutit à la dissoudre, l'autre à la reconstruire sur une base plus rigoureuse et analytiquement plus efficace. Empruntant cette seconde voie, il analyse successivement plusieurs problèmes : la distinction entre l'imaginaire et le symbolique et leurs rôles respectifs dans la production des rapports sociaux. Il cherche ensuite quels sont parmi tous les rapports sociaux, ceux qui ont la capacité de lier un certain nombre de groupes humains en un Tout qui leur confère une identité globale partagée, qui en fasse une société. Il montre que seuls des rapports politico-religieux ont une telle capacité dont sont privés les rapports de parenté et les rapports économiques. Enfin réfléchissant sur le

1. This text was pronounced as the $1^{\text {st }}$ Inaugural Raymond Firth Memorial Lecture, at Marseille, July 8, 2005, at the $6^{\text {th }}$ Conference of the European Society for Oceanists.

* EHEss, Paris. godelier@ehess.fr 
order for this job to constitute a scientific, critical approach more necessary than ever for analyzing and understanding the new world order that sprang up with the fall of the Berlin Wall and the Twin Towers attack on 9/11/2001.

Keywords: Polynesia, Melanesia, Tikopia, Tonga, making babies/children, kin-based societies, political-religious relations, imaginary-symbolic, postmodernism, deconstruction, participant observation, writing ethnography.

Whoever has not yet read We, the Tikopia (1936) or The Work of the Gods in Tikopia (1940) should rush to the library and discover two classics of our discipline that weave a spell with the wealth and detail of their ethnographic data, their clarity of style and the empathy present on every page between the young anthropologist and the men and women who guided him to an understanding of their conception of the world and their manner of living together.

\section{Raymond Firth, a great work and a great man}

In the first part, I would like to look back over the outstanding points of a work and an exceptional career of a man whose life spanned more than a century, since Raymond Firth, born in 1901 in Auckland, died in Great Britain on February $22^{\text {nd }}, 2002$. Firth thus witnessed all of the important changes and transformations in our discipline since Malinowski put fieldwork center stage with the publication of his Argonauts of the Western Pacific in 1923. It was after reading Malinowski that the young Raymond Firth switched from the study of economics to anthropology, although he retained his keen interest in the economic relations people contract with each other to produce their means of existence and their material wealth. It was Malinowski himself, to whom Firth had been introduced by Seligman, who in 1934 invited him to take up a lectureship at the London School of Economics. In 1944, Firth succeeded Malinowski and occupied his chair until his own retirement in 1968. It was, in fact, while reading economic anthropology (which was my initial area of interest in anthropology) that I first encountered and came to admire Firth's work. That was in 1967. I had had a serious accident in métier d'anthropologue, l'auteur dégage un certain nombre de conditions à remplir pour que ce métier constitue une démarche scientifique et critique plus nécessaire que jamais pour analyser et comprendre le nouvel ordre mondial né avec la chute du mur de Berlin (1989) et les attentants du 11 septembre 2001.

Mots-ClÉs : Polynésie, Mélanésie, Tikopia, Tonga, conception des enfants, sociétés fondées sur la parenté, rapports politico-religieux, souveraineté, imaginaire-symbolique, post-modernisme, déconstruction, observation participante, écriture ethnographique.

New Guinea and had been transported to Sydney for medical treatment. There I spent a good deal of time in the university library, where I read Firth's Primitive Polynesian Economy, published in 1939. One passage in particular struck me, which I copied out:

«I analyzed the economic structure of the society because so many social relationships were made most manifest in their economic content. Indeed the social structure, in particular the political structure, was clearly dependent on specific economic relationships arising out of the system of control of resources.» (Firth, 1965 [1939]: XI)

At the time, I had approached economic anthropology as a Marxist; in other words, I was tempted to make economic relations the foundation of social life, to see them as the key to understanding the kinship system, the political relations and the religious institutions found in a society. It seemed to me that Firth was pointing in the same direction; but in reality, later in the book, he stressed that the explanation for the inequality between a Polynesian chief and the commoners lays basically in the representations of the divine origin of the chief's power rather than in the material sphere of human existence. This statement appeared to contradict the preceding passage and to stem from a rejection of Marxism. In reality, I was later to realize that Firth was right and that he had clearly perceived the limits of the Marxist explanation of the nature of societies and their history by modes of production alone, Marx's «meta-narrative», as Lyotard termed it in his $1977 \mathrm{La}$ Condition postmoderne. Firth had not waited for postmodernism to voice his skepticism about allencompassing theories; he took the same attitude toward Lévi-Strauss' structuralism.

No other anthropologist has devoted nine books and dozens of articles to describing and 
explaining the workings of a small society of slightly over 1500 people living on a little island in the eastern Solomons. In 1928, when Firth first set out into the field, the Tikopia's old ritual and political organization was almost intact, as the missionaries that had arrived in 1924 had not yet had an impact on their social organization. Alternatively, the second time he came to do fieldwork, in 1953, he found the society deeply divided. One of the four clan chiefs had converted himself to Christianity, together with all of his fellow clan members, in order to destabilize his rival, the Te Ariki Kafika, the highest-ranking chief on the island and the key figure in the fertility rites. In 1962, on the occasion of Firth's third stay, the whole island had converted to Christianity, and the major rituals had been abandoned; but the chiefs still had political authority over the rest of the population.

In sum, three periods of fieldwork in the same society several years apart enabled the anthropologist to observe the fundamental changes that had occurred in this society, to circumscribe the causes and mechanisms, in short, to see and to understand how local history came to pass, which, on Tikopia as elsewhere in the South Pacific, could no longer be explained by internal causes alone but called on external forces resulting from Western expansion on a global scale. In 1985, Firth sent me a copy of his Tikopia-English dictionary and, in 1990, in collaboration with Mervyn McLean, he published another book, completed by a tape, entitled Tikopia Songs: Poetic and Musical Art of a Polynesian People of the Salomon Islands (Cambridge University Press).

But Tikopia was not enough for Firth. In 1939, with his wife Rosemary, he began a field study of a Malaysian community of peasant fishermen, on whom he published, in 1946, Malay Fishermen: Their Peasant Economy. Back in London, he launched two research projects on family and kinship in a working-class area of London, then in a middle-class area, thus becoming a pioneer of European urban anthropology.

But Firth did more than write monographs. He has to his credit ten or so theoretical works in which he admits to being skeptical of grand theories and concentrates instead on analyzing Elements of Social Organization (1951), Symbols, Public and Private (1973) and lastly, a few years before his death, Religion (1996), a book in which this son of a very strict Methodist father stoutly affirmed that religion, «including ideas of God is clearly a human construct», which can of course encourage one to respect and love others but also can act «as a force of destruction as violent collisions of religious wars have demonstrated in many faiths».

Here is a great man and a great work.

\section{Is anthropology dead? Postmodernist voices}

But a question arises: We hear a variety of voices questioning the legitimacy of anthropology and denying its scientific value. Why then celebrate the memory of a hero of this discipline if it is, if not dead, at least in rapid decline?

I believe these colleagues are in error; but since it seems that a number of anthropologists are going through a crisis, we need to listen to their reasons and offer a response. For the reasons are not all the same. Some invoke historical reasons; others, epistemological grounds. The first consider that the events of the end of the twentieth century deprived anthropology of the object it had set for itself in the nineteenth century. Born at the height of the colonial, commercial and cultural expansion of a few Western nations, some of which ushered in the era of industrial market production, anthropology, or ethnology, as it was then known, set itself the task of discovering and understanding the ways of thinking and acting found in the hundreds of societies Western nations were gradually conquering by dint of their weaponry, their trade and their administration. And these nations felt they had every right to do so because they came bearing civilization and the one true religion, Christianity. But it was also in the twentieth century, in the last decades of that time in world history which was to end in the independence of the colonized peoples, that numerous publications, whose scientific value had not yet been called into question, focused on the Trobriand Islanders, the Tikopia, the Nuer, the Kachin, and many others.

This time is now the past. The Tikopia, the Nuer, the Kachin and the rest still exist physically, but their social structures and their cultures have changed profoundly. Today we are going through another phase of global domination by a West, without a rival since the fall of the Berlin Wall in 1989 and the collapse of the socialist system but also deeply contested, as shown by the 9/11 attack on the Twin Towers. In today's globalized world, local cultures are increasingly hybrid mixtures cobbled together from bits and pieces of precolonial customs that escaped the ravages or have been reinvented, tailored to Christianity and the new forms of social organization borrowed from or imposed by Western 
culture: parliamentary regime, political parties, churches, sects, new calendar, and so on.

In view of these facts, some have proclaimed the death of anthropology and its replacement by sociology, better suited to analyzing evermore-urbanized societies caught up in the global market, with a portion of their population forced to emigrate in search of a living or a better life. According to these prophets, anthropology has become useless or even undesirable in those societies where it once flourished and now has no other choice, if it is to subsist, but to fall back on the study of the Western world that engendered it, and there to apply the methods and concepts it developed to analyze the way the non-Western world thought and lived.

But this view of the death of anthropology in the rest of the world and its rebirth in the West is flawed because it overlooks a certain number of facts. Throughout the twentieth century, anthropologists continued to do fieldwork in Europe and the US, and not only to study ethnic minorities, Basques or Chicanos. Furthermore, urban anthropology was not a product of decolonization. Raymond Firth was one of its pioneering figures since, at the end of the Second World War, before the end of the British Empire, he had already launched his two studies on the evolution of the family and kinship in London.

Listening to me, you are probably tempted to conclude that all is well with our discipline. Born in the colonial era, it has survived the decolonization of non-Western countries and has even found a second wind and an unlimited field of action in Western countries. Do not cry victory too soon, though, because, for the last twenty years, or nearly, another group of our colleagues has been busily deconstructing anthropology. They declare to all who will listen that, before the colonial era and after, anthropology never was and never has been what it claimed to be, namely: a «science» of understanding others. To prove this, a few have undertaken a critical re-reading of the major monographs that claimed to give us an understanding of the Nuer, Dinka, Tikopia and others. On the positive side, they have pointed out the silences that pervade these texts: that of women, who were usually absent, that of the colonial administrators, and so on. But others went further. For them, these monographs were no more than narrative fictions, in which the author - a Westerner - in abstract terms, tells more about him- or herself than about others, disguising his or her prejudices and stereotypes as scholarly formulas. For some of the most virulent postmodernists, no anthropological text, regardless of the author's knowledge of the language, length of stay, or the nature and richness of the study, possesses any particular authority that would enable us to understand the way individuals and groups belonging to societies other than our own think and behave. For these critics, the anthropologist's interpretation is only one among any number of equally «true» interpretations.

Have no fear; I am not going to lump together everyone who claims to be or whom others claim to be a «postmodernist». Clifford Geertz is not Stephen Tyler; Jameson is not Marcus, and Marcus is not Rabinow. With the exception of Geertz, many are ex-structuralists and/or ex-Marxists who have been struggling to survive ever since Lyotard declared that our postmodern condition of existence began with the death of major narratives, or meta-theories. In place of Lévi-Strauss, Meyer Fortes, Leach or Sahlins, the new maîtres à penser were Derrida, Foucault, Deleuze and, of course, Lyotard and a few others. Seen from France, the spectacle was sometimes astonishing. Two thinkers like Foucault and Derrida, strongly at odds in France, found themselves cheek by jowl or even lumped together on the same philosophicalanthropological page by an American colleague. Yet Foucault's early work falls under the heading of history of Western institutions: prisons, mental hospitals, etc.; whereas, in his second life, he turned to a history of sexuality and the processes of personal individuation. Derrida strove to demonstrate the twofold impossibility of realizing and surpassing Western metaphysics as revived by Heidegger, after Kant, Marx and Nietzsche had, each in his own fashion, proclaimed the irreversible death of Western philosophy.

\section{Positive deconstruction; or, deconstructing, not to dissolve but to reconstruct}

Let me be clear. It is entirely normal from time to time to deconstruct the concepts and conclusions that anthropology presents as «truths». All sciences do this and must do so. But there are two ways of deconstructing a discipline: one makes it possible afterwards to reconstruct it with greater conceptual and methodological rigor and a clearer awareness of its strengths and limits. The other ultimately leaves the discipline in a thousand pieces or simply liquidates or dissolves it as we see in the case of anthropology, for example - into the amorphous essays we find ranged under the heading of Cultural Studies. 
In the rest of this lecture, I will attempt to keep to the first path, that is to say: positive deconstruction. Among the celebrated truths I believe we can now pronounce dead, I am going to try to show that no society has ever thought that a man and a woman were sufficient to make a child, whether the baby was an ordinary or an extraordinary being, a child or a man-god. From there, I will try to show that the famous statement that there is something called «kin-based societies» is meaningless. In no place and at no time has it ever been the case that kinship relations - even in societies lacking castes, classes or a State - and even less the family, has the ability to draw a number of kin groups or other social groups together into a society. I will also show that the economic relations of production and exchange do not have this capacity either. The question is, then: what social relationships have the capacity to make societies and how do they do this? Afterwards, I will look at the nature and the importance of the imaginary realities that are one of the constituents of kinship and politicalreligious relations, and at the role of the symbolic practices through which these relationships are staged and enacted. And last of all, I will draw a few conclusions for the exercise of our profession in our globalized world. For, alongside a number of truths that have died and should be buried with all due haste, there are some others worth re-stating and putting into practice.

\section{Nowhere do a man and a woman suffice to make a child. A few examples}

Before a human baby is born it must have been conceived. I have compared the representations once and sometimes still held by twenty-six societies of the way babies are made: of these societies, thirteen are in Oceania, four in Asia, four in Indian America, three in Africa and two in Europe. Much to my surprise, in not one of these societies were a man and a woman sufficient to make a child. What they made was a fetus, which became a whole child only through the intervention of yet other agents: ancestors and/or gods. I will limit myself to four examples.

First of all, the Baruya, a New Guinea society divided into patrilineal clans and formerly characterized in political-religious terms by largescale initiations of males but also females. The Baruya believe that the man's semen produces the bones, the flesh and the blood of the fetus growing in the woman's womb, while the woman is nothing but a container, a bag, gilya, who transmits nothing to her child. As soon as the woman senses she is pregnant, the couple has intercourse as often as possible because the man's semen nourishes the fetus. The father is thus the sole genitor of a fetus that as yet has no nose, mouth, fingers or toes. It is the Sun, the father of all Baruya, who finishes the child in the womb and imparts his breath. The child is born with a human body, it breathes but it still does not have a soul. Later, a spirit-soul enters the child's body when the father gives it a name, which is that of a patrilineal ancestor. But if the baby is a boy, he must be born again, this time from the body of men. That is the aim of the male initiations, which bring together all boys of the same age whatever their lineage or home village. [Around the age of ten, they are separated from their mother and the women's world. At this time, the boys are introduced to homosexual relations with the third- and fourth-stage initiates, young men who have not yet had sexual intercourse with a woman and who give the boys their semen to drink.] Through this exclusively male rebirth, Baruya men take upon themselves the right to single-handedly represent and govern their society, without the participation of women.

It is clear that the Baruya's pre-contact representations were directly linked to the nature of their kinship system, which combines patrilineal descent reckoning with political-religious relations that go well beyond the sphere of relationships between kin, lineages and clans. They not only affirm the Baruya's shared identity as sons and daughters of the Sun, a cosmic power but also a tribal god who endowed them with their human form and the breath of life; they also legitimize the fact that one part of the society, the men, gives itself the right to represent the whole society, to govern it, and as a group to exercise their domination over the women and non-initiated males.

I will take a rapid look at two other Oceanic societies, chosen because both entertain two conflicting theories of the way babies are made: the Telefolmin, who live in the mountains at the headwaters of the Sepik River, known to us through the work of Dan Jorgensen; and the inhabitants of the former «kingdom» of Tonga.

The Telefolmin kinship system was cognatic, with no clans or lineages. Village life centered on the male cult centering on the bones of famous men, one of the aims of which was to curb the slow drift of the universe towards nothingness. Women were strictly excluded from this worship. There was an «official» theory to explain the way children were made, publicly shared by men and 
women, according to which a fetus is formed when «penis water» mixes with the woman's vaginal fluids. This theory is in accordance with the cognatic character of their kinship system. But the women had their own secret theory. According to the women, sperm indeed mingled with their vaginal fluids to make the child's flesh and blood. But it was their menstrual blood, and it alone, that made the bones. It was the women, then, who had made the bones of the great men worshipped by the men in a cult from which women were excluded. You will now be less surprised to learn that, in 1978 and 1979, the Telefolmin women, converted to Christianity and led by a Protestant minister from another village and a neighboring tribe, destroyed the sacred relics and burned the cult houses.

The example of the former kingdom of Tonga, one of the most stratified Polynesian societies before the Europeans arrived, presents us with fundamental historical changes that occurred over the centuries preceding the arrival of the Europeans and which widened the gap between the mass of commoners without rank or title (the tua) and the eiki, who formed a sort or aristocracy around the lineage of the Tu'i Tonga and his sister, the Tu'i Tonga Fefine, direct descendants of the most powerful god in the Polynesian pantheon, Tangaloa. An absolute barrier separated the eiki from the rest of the society, for, as in Tikopia, they were the sole possessors of mana, the power present in their bodies, which bore witness to their closeness to the gods. All eiki had authority over a portion of the territory, and over the person, labor and products of those who lived there. But, unlike the ariki, the Tikopia chiefs, the eiki's authority was always delegated and flowed from the person of the paramount chief, the Tu'i Tonga.

Before the Europeans arrived bringing Christianity, two theories coexisted in Tonga. The oldest and most widespread corresponded to the cognatic nature of their kinship system and their religious beliefs, and gave the gods and the ancestors the preponderant role in human destiny. According to this theory, the man made the baby's bones and skeleton from his semen, while the woman made its flesh and blood from her own blood. Then a soul, a gift from the ancestors and the gods, took possession of the fetus and made it a child.

In the second model, this time the whole substance of the fetus came from the woman: its flesh, blood, bones, skin and so forth. Semen played only one role: it kept the menstrual blood in the uterus. The clot that formed was made into a fetus and then into a child with the help of the gods, and above all of the Tu'i Tonga, the paramount chief who is a man-god. In this version, the man completely disappears as his children's genitor. He prepares his wife for fertilization by the Tu'i Tonga, who, as Françoise Marsaudon has shown, impregnates all the women of his kingdom with his semen that has become a fecundating breath, a «pneumatic» seed, as the Ancient Greeks would have said. We see that the second model was not conceived to magnify women's procreative capacity but to exalt the mana, power of the supreme eiki, the Tu'i Tonga, as well as to exclude all male commoners from the process of creating human life. In this way, the Tu'i Tonga added to his responsibility for the fertility of the earth and the sea, stemming from his divine nature and the rites over which he presided, the responsibility for impregnating all the women of his kingdom. He thus became the «Father» of all Tongans, and his kingdom became one kainga, one big family, attached to his person and dependent on him. This second model seems to have arisen directly from the profound political and ideological mutations that ultimately made the Tongan nobility a «quasi-class», with the right to dispose of the land and the person of the mass of commoners. Unlike the guyau and the Trobriander paramount chief, or the four Tikopia ariki, the Tongan aristocracy had ceased taking part in productive labor in order to devote themselves entirely to the performance of rites, warfare and pleasure, while nevertheless controlling the production of subsistence goods and their redistribution. The offerings owed to the chiefs and the gods already smacked of tribute and forced labor, and no longer had the taste of festivals and free gifts.

But where does the West stand in all this? Might we be the only civilization to think that a man and a woman alone, through their sexual union, suffice to make a child? How wrong we would be. Before the West discovered that women are $\mathrm{XX}$, and men, $\mathrm{XY}$, the way babies were most usually thought to be made had its source in Christian thought. So, what is a child for a Christian?

For theologians, a child is first of all an embryo and then a fetus resulting from sexual intercourse between a man and a woman joined by the sacrament of marriage, and who, when their bodies unite, become one flesh, una caro. Their single flesh is passed on to their children, who are «flesh of their flesh». This representation corresponds to the nature of European kinship systems, which are cognatic and use an Eskimo-type terminology that emerged in 
Europe at the end of the Roman republic, after the disappearance of the old «Sudanese»-type Latin system. Such a representation of sexual intercourse would be completely unacceptable and disgusting for a Baruya, a Trobriander or a Telefolmin woman. But there is more. For a Christian, a man and a woman are not sufficient either to make a child. All they can make is a fetus, which lacks the essential ingredient: a soul. This soul is introduced into the child's body when God so chooses. What is this soul like? Hildegard von Bingen, a great twelfth-century mystic, described and even painted one. The soul is like «a ball of fire that in no way resembles the human body and which takes possession of the heart of this form», the fetus, which in turn looks like a miniature human being, a homunculus.

But that is not the whole story either. For Christians, each human being receives a distinct soul from God, which can never be that of an ancestor, as in the case if Trobrianders and Inuits. By endowing each of us with a soul, God continues, down through the centuries, to create the world. That is why missionaries of every Christian denomination do not like ancestor cults, especially if the ancestor effects his or her own reincarnation without the help of God. We saw this in the case of China, when Western missionaries forced new converts to abandon ancestor worship and break their tablets. The Chinese Emperor, perfectly aware of the close connection between respect for ancestors and obedience to the State, quickly put a stop to Christian proselytizing and expelled all missionaries from the Kingdom.

Whether it is the Baruya man's semen alone that makes the fetus, or the woman's blood alone that flows in the bodies of Trobriander children, whether the Tu'i Tonga fertilizes the women of Tonga with his spermatic breath or the Christian God introduces into the body of each child that is born a soul that cannot be confused with any other, all these representations of the way children are made are realities of the mind, imaginary explanations staged and enacted through various symbolic practices: ingestion of semen for the Baruya, baptism for Christians. But they also have consequences for Baruya and Christian social life that are, this time, neither imaginary nor purely symbolic.

\section{Concerning the role of kinship, the economy and political-religious relations in making societies}

Why is it that kinship relations do not have the capacity to make a certain number of human groups into a society? What social relationships have this capacity? Failing kinship relations, might it be relations of production and exchange, the mode of production as suggested by Marx and his followers? Once again, my reply is negative, even though I was once a Marxist myself. What answers did my seven years of fieldwork among the Baruya provide? After having, with the constant help of the Baruya, recorded the population of every one of their villages and hamlets, pieced together the genealogy of every person, recorded all exchanges of women, all alliances between lineages over five generations, after having spent every day for a year measuring more than six hundred gardens, taking down the names of the individuals and the lineages that had cleared the space in the forest, and the reasons for and the circumstances of these clearings, after having recorded the names of all of the men and women who then cultivated these plots and shared what they produced, and noted the relations of kinship, neighborliness or friendship that connected these men and women, I came to a twofold conclusion: Neither the relations of kinship and the many kinds of exchange that accompanied the exchange of women, nor the economic relations of cooperation and exchange involved in the production of their material conditions of existence and their wealth (pigs, shells, etc.) created general ties of social and material dependence between each Baruya and the other members of his or her tribe. None of these relations was capable of providing a common basis on which to build a society. These were in no way «allencompassing» social relationships, that is relationships capable of making all these kin groups into a whole, an overarching social group existing as such and capable of reproducing itself as such under the shared name of «Baruya».

In the case of the Baruya, what were those social relationships that were capable of drawing them all together into a single whole so that each depended on all the others, whatever their lineage and their village, in order to reproduce themselves as Baruya? These social relationships were the ones engendered by the workings of institutions, which in turn entailed and required the material and social cooperation of all lineages and all villages in order to exist and reproduce themselves. The institution, in this case, was the large-scale male and female initiations. Every three years or so, for the space of several weeks, everyone, men and women, mobilized to build the Tsimia, the big ceremonial house where part of the initiations of the boys and young men took place. But a year earlier, they had needed to 
make new gardens in order to feed the initiates and everyone who helped in their initiation, feed and take care of the hundreds of guests from neighboring tribes, friends and enemies having struck a truce for the duration of the ceremonies and having come to see those with whom they would marry or fight tomorrow. It was in these circumstances that the Baruya expended additional labor in order to produce a surplus over and above their ordinary needs, destined here not to reproduce their own lineage but to reproduce the Baruya as a society exercising what we could call a kind of sovereignty over a territory whose boundaries are known if not recognized by their neighbors. This shared sovereignty that must be defended by armed force is manifested by the fact that the Baruya, whatever their clan name and lineage, carry a «big name» that unites them. They are BARUYA. Where does the name come from? It is the name of the clan that claims to have received, directly from the Sun, at the time of the first men, the men of the «dreamtime», or wandjinia, the kwaimatnie. Kwaimatnie are the sacred objects and secret formulas enabling the Baruya to re-engender boys without the aid of women, and to make them into men: warriors, shamans and cassowary hunters, with the help of the Sun, the Moon and the founding ancestors.

I therefore conclude that what makes «society» the world over, and not only in the case of the Baruya, are the social relations that human groups (and not only kin groups) produce among themselves in order to affirm their shared sovereignty over a territory and which thereby find themselves joined together, in view of reproducing themselves as a whole, whatever may be the nature of the kinship relations or the economic relationships linking each of these groups to others belonging to the same society. Furthermore, we have seen clearly that the way in which a political-religious sovereignty over a territory is affirmed and exercised is not to be confused with the way the resources of this territory are exploited, with the mode of production and exchange that characterize a given society.

I will cite several facts that adduce further proof to the general thesis I have just set out. First of all, the fact, acknowledged by both the Baruya and the neighboring friendly and hostile tribes, that the territorial group that now calls itself the Baruya did not exist three centuries ago. It was in the wake of a bloody conflict between the lineages and villages of the Yoyué tribe, whose territory lays near Menyama, that the survivors of several clans, one of which was called «Baruya», sought refuge with the Andjé, at a distance of a few days' walk. There, after one or several generations during which their children had been initiated alongside those of the Andjé, the refugees conspired against their hosts, massacred a number of them with the complicity of a local clan, the Ndélié, and took over their territory. Then the descendants of the refugees and the native inhabitants who had helped them erected their own Tsimia in order to initiate their boys and make them into warriors or shamans. They took the name Baruya, from the name of the clan that owned the most powerful kwaimatnie.

Firth describes a comparable process in his enormous body of work devoted to the social organization and history of the Tikopia islanders. As you know, the islanders were divided into four non-exogamous clans ranked in the following order: Kafika, Tafua, Taumako and Fangarere. The chief of the Kafika clan, the Te Ariki Kafika, occupied the highest position in the cycle of rites ensuring the fertility of the land, the sea and the people, described by Firth in the Tikopians' own words as «the work of the gods». The preeminence of the Te Ariki Kafika was based on the fact that the central god of the Tikopian pantheon was the divinized ancestor of the Kafika clan. This ancestor was an exceptional being, who gave the Tikopians the laws and rules that organize their society. After having been killed by a jealous rival, he joined the gods in the sky, the atua, and received from the most powerful god the mana that established his supremacy over the other local gods and gave his descendants, the Kafika clan chiefs, primacy over the other chiefs.

Note in passing the parallel between this story founding the Te Ariki Kafika's power and that of the Tu'i Tonga, the man-god who ascended into heaven to meet his father, the most powerful god in the Polynesian pantheon; killed by his divine brothers, he was restored to life by his father, who gave him first place among his divine sons and among all human beings. We are looking, here, at facts of the same nature. It is the political-religious relationships that make the Tikopia clan into a whole and ensure the reproduction of this whole. With one fundamental difference with respect to the Baruya society: in Tikopia the chiefs hold the rights to the land and grant commoners the right to cultivate it.

It is because of these political-religious relationships, then, that Tikopia society operated as a whole. However, the four clans that comprise this society today descended from the human groups that occupied the island at different times 
and originally came from a variety of islands, Ontong Java, Pukapuka, Anuta, Tonga, Rotuma, etc.; moreover, these groups fought before finding their place in the politicalreligious hierarchy connected with the «work of the gods» and placed under the ultimate authority of the Te Ariki Kafika.

I am going to add one last example, taken this time from outside the South Pacific, one that is often in the spotlight on the present-day world stage. The case of Israel illustrates the difference between a «community» and a «society», a fundamental distinction that sociologists and anthropologists often have a tendency to forget. The Diaspora Jews, who lived, sometimes for centuries, in other societies in Russia, Argentina, France, the United States, Morocco, etc., made up particular communities within the host societies, but they themselves were not a society. But, after the Second World War, many Jews left, and are still leaving their countries and moving to Israel. To be sure, they find the same divisions as before between Sephardim and Ashkenazim, between Russian Jews and Moroccan Jews, and so on. But they now all form a «society» that is constructing itself on a territory conquered by armed force and governed by a parliamentary State charged with representing and defending the interests shared by all citizens of the State of Israel, including the Palestinian Arab minority living in this territory.

\section{Concerning the distinction between the imaginary and the symbolic, and the roles they play in produc- ing social relations}

I now come to the last point: the distinction between the imaginary and the symbolic, and the necessity of not confusing the two if we want to understand the role each plays in producing the many forms of social life that we see. The imaginary arises in the mind. It is made up of all of the representations humans have conceived or will conceive of the nature and origin of their universe and the beings that inhabit it. The imaginary is first of all a world of the mind, the world of representations. And like all representations, it is at the same time the product of an interpretation of what it represents. The imaginary is the totality of all the interpretations human beings have invented to explain to themselves the order or disorder that reign in the universe, so as to draw conclusions for the way humans must organize their life in society. The imaginary is therefore a real world, but one composed of realities of the mind, mental realities (images, ideas, opi- nions, reasonings, etc.), which, insofar as they are inside the individual mind, remain unknown to those around and can therefore not be shared by them or act on them.

The symbolic is comprised of the many means by which originally imaginary realities are embodied in a material support that endows them with a perceptible form and mode of existence that allows them to be seen and communicated. This «material form» can be a word, a gesture, a posture or a body decoration, an object that has been made or found. But whatever the forms and material realizations, the symbolic is nothing but all of the signs invented by human beings to communicate. In their essence, symbols partake of language, but their language overspills the words of languages and speech on all sides; symbols are used to stage and enact the realities invented by the mind so that we may act on the world and on ourselves, and achieve the objectives we have set for ourselves.

The imaginary is not the symbolic, then. But it cannot have any social existence or effectiveness if it is not embodied in symbolic signs and practices. Symbols die, however, or take on other meanings when the contexts in which they arose and the minds that worked them out disappear from the daily lives and memories of men and women.

The analysis cannot end here, however. For the role of the symbolic largely surpasses making the invisible visible, making mental realities into social and material realities which fall under the sway of the senses. The role of the symbolic is also to endow imaginary realities with «truth» once they have taken the form of the social realities in which the fundamental stakes of society reside: access to the gods, control of the land, exercise of power.

Because symbolic practices endow mental realities with the twofold quality of being «social realities» whose existence at the same time furnishes proof of their «truth», we understand why these practices also attest to the «legitimacy» of the social order they create or in which they are contained. Let us take for example the Baruya rites that stage their myths and transform their beliefs into visible truths in such a way that the mental realities in the form of myths apparently begin to exist independently of the minds of those who conceived and developed them. But the same problem arises each time. What appears to be the "true reality» for members of one society usually appears as a «purely» imaginary reality to outside observers who do not share the same cultural and social universe. 
It is easy for us to select examples from our preceding discussion to illustrate our conception of the imaginary and the symbolic. All we have to do is to recall two ethnographic facts already analyzed: the myths that found the relatively modest power of the primary Tikopia chief, the Te Ariki Kafika, and those founding the formerly grandiose power of the Tu'i Tonga and his sister, the Tu'i Tonga Fefine, the paramount chiefs of the kingdom of Tonga. Both of these chiefs owed their rank and power to the divine character of their lineage's founding ancestor.

But in Tikopia and Tonga we are no longer among the Baruya. The issue involved in these myths and rites is no longer merely to establish the men's right to govern the society and exercise their dominion over the women. Baruya society is not divided between nobles and commoners. In Tonga and Tikopia, only noble men and women have rights over the land, the waters of the rivers, the sea; and they merely allow commoners to use them. The nobles alone perform the large-scale seasonal rites because they themselves are of divine origin. And in Tonga, the Tu'i Tonga as well as the sino'i eiki, the "chiefsin-the-body», had almost absolute power over the person and the possessions of the commoners. This was not the case in Tikopia, where, according to Firth, in the area of the economy, inequalities were especially a question of degree, whereas in the spiritual and social domains the inequalities were of nature, and irreducible.

In short, all of our analyses lead to the opposite conclusion from Lévi-Strauss and the so-called «symbolic» theories of anthropology. In his famous preface to Mauss' work (1950), Lévi-Strauss affirmed the primacy of the symbolic over the imaginary, a thesis that Lacan took up three years later in his "Discours de Rome», in which he broke with Freud. For me, if one of these domains has primacy over the other, it is clearly the imaginary. Without the idea that Jesus of Nazareth was the Son of God who died on the Cross to redeem humanity from its sins, the symbol of the Cross - two pieces of wood, one shorter than the other, joined at the top of the longer piece - has no special meaning. Contrary to Lévi-Strauss, «myths do not think themselves» through men, and, contrary to Roy Wagner, «symbols don't stand for themselves».

In reality the primacy lies neither in the imaginary nor in the symbolic. It lies in the nature of the real issues at stake in society: access to land, to power, to the forms of wealth in a society, to control of men's and women's labor, to the products of their labor, to the gifts and favors of the ancestors and the gods. These are the fundamen- tal assets to which the imaginary representations of the world and of society, as well as the social institutions to which they have given rise, provide access. It is therefore essential to understand that the social consequences of imaginary representations and the symbolic practices that endow them with the quality of being true, that these consequences themselves are not imaginary and cannot be reduced to symbols. We have seen this in the example of the Baruya society: there, women were really and not symbolically deprived of the right to own land, to use weapons, to produce the bars of salt money; and their access to the gods was severely restricted.

The conclusion to be drawn from these facts is clear: the imaginary and the symbolic are distinct, inseparable realities, but they do not exhaust the totality of social reality. Social reality is always and everywhere constructed from stakes that are not only imaginary nor purely symbolic. These can be summed up in a few questions: who in the society has the right to exercise power and why? Who has access to the wealth and why? Who is allowed to communicate with the gods and ancestors and why? Who is allowed to control the person, labor and product of the labor of others and why? History offers us an enormous range of answers to these questions, which everyone can understand and which are crucial to understanding history. Our whole analysis of the necessity of distinguishing between the imaginary and the symbolic in order to understand both the ways in which they are conjoined and the role each plays in the production of societies leads us to conclude that the opposition accepted and even cultivated by many anthropologists, beginning with Boas, between cultural anthropology and social anthropology is a partial (in both senses of the word) approach to the historically dated social realities we are seeking to analyze and understand.

\section{Concerning a few truths worth speaking}

Having slain these venerable and venerated anthropological «truths», I will conclude by affirming two or three other «truths» still worth re-stating and even more worthwhile practicing.

Anthropology will continue to develop in both non-Western and Western societies. Furthermore, anthropologists no longer come only from the West. More than ever we must ask ourselves: under what conditions can anthropology be a scientific discipline and not the projection of the ethnocentric biases of the anthropologist, 
whether he or she is from the West or not? In reality, anthropology together with the other social sciences can exist as a scientific discipline because they presuppose two basic facts that can be summed up as follows: the social otherness of the other is never absolute but always relative, and whatever some people have invented in order to act on the world and on themselves, other people can understand without necessarily having to identify with it.

How are we to understand something we have not invented ourselves or experienced in our own society? For an anthropologist, we know how to proceed. It is indispensable for the anthropologist to construct a cognitive Self, distinct from the social Self bestowed by birth and the social environment; and from the intimate Self, the Self of fortunate or unfortunate encounters with others. This cognitive Self is full of concepts, theories and methods, all attached to a historical context. But whatever the context, the anthropologists' first rule is that they must decenter the cognitive Self with regard to the intimate and social Selves. The second rule is that they must maintain a state of critical vigilance against the intrusion into their cognitive Self of their own society's ways of thinking and acting. In addition, concepts and theories should be used as tools to be abandoned or modified when necessary in order to account for what is observed. The crucial experience, however, is fieldwork. But fieldwork is not merely a few months spent in investigation and chewing the fat around the fire with a few informants. Fieldwork involves methodical observation and participation. Methodical observation means starting by learning the language, gaining acceptance so as to be present in the various contexts of the lives of the people of the society under observation. But above all it means months of systematic studies carried out on the various aspects of the social life of the society. This is how one learns the rules people follow in order to think and organize their actions on others and on themselves. And if the studies are systematic, one will find out whether or not people say what they do and do what they say.

\section{Participant observation: participation in what and how far do you go?}

But the big difference between anthropologists and the members of the societies they observe is that, for the latter, their rules, their representations and their values constantly serve to produce their concrete conditions of exis- tence. This is not the case for the anthropologist. We talk about participant observation, but what do they participate in and how far should they go? Everyone knows that an anthropologist's participation in the life of others very quickly reaches its limits. It is not enough to go hunting a few times with the Inuits and on those occasions help feed the others and feed oneself. To participate fully, the anthropologist would have to marry into the band, have children and raise them. This is not what happens, and it is not necessary for it to happen for anthropologists to do their job.

The last step comes when it is time to write about others. For the cognitive Self is not only an intellectual Self, it is also an ethical and a political Self: an ethical Self because anthropologists adhere to a code of practice; a political Self because anthropologists have to be aware of the relationship between their society and the society that has taken them in. Last of all, anthropologists have to write books, make films, etc. It is therefore advisable to have some talent for writing or making films so as to arouse the necessary empathy between readers and spectators and the individuals of the society one is talking about. But the literary qualities of an anthropologist do not make the text a literary text, and this for two reasons that Derrida and his emulators have not taken into consideration. The first is that, unlike Macbeth, which sprang from Sheakespeare's head, the Kula existed well before Malinowski set foot on Kiriwina. The second is that no one can complete Shakespeare's work after his death. Whereas Fred Damon, Nancy Munn, Annette Weiner, Jerry Leach, etc., were able to enrich and correct Malinowski's analysis of the Kula fifty years later.

Anthropologists thus did not wait for Geertz's «Notes on the Balinese Cockfight» (1973) or Marcus' text on «The Uses of Complicity in the Changing Mise en Scène of Anthropological Fieldwork» (1997) to develop a critical reflexive awareness of their own concepts and practices. It is erroneous and absurd to claim that, throughout the colonial era the relationship between Western anthropologists and the men and women who were their informants and collaborators was nothing more than a collusion to produce «fictions that each side accepts» (Marcus, 1998: 110). In the conclusion to the last article he wrote on the Tikopia, entitled «The Creative Contribution of Indigenous People to their Ethnography» (J.P.S. 2001, vol. 110, no 3), just after he had received the Polynesian Society's Nayacalou Medal for «significant 
publication on the Island Pacific», Raymond Firth, who had just turned 100, wrote:

«Be all that as it may, for me ethnography and social anthropology in general as they have developed, have been the creation of both alien western and indigenous contributors.» (Firth, 2001: 245)

That was in 2001. Firth died a few months later, on the day our sister association, the ASAO, was meeting in New Zealand, in the city where he was born and at the university where he received his first two degrees.

\section{The future of anthropology}

Today more than ever, anthropology is conscious of its analytical and critical strengths, but also of its limits; for it cannot account singlehandedly for the complexity of societies and their transformations down through time. Having shaken off the origins that tied it to Western expansion and domination of the rest of the world, anthropology has become a powerful tool for analyzing the changes and contradictions besetting the modern world born with the fall of the Berlin Wall in 1989 and the attacks on the Twin Towers on September 11 $1^{\text {th }}, 2001$.

\section{BIBLIOGRAPHY}

FIRTH Raymond, 1936. We, the Tikopia, New York, American Book Company.

—, 1939 ( $2^{\text {nd }}$ ed. 1965). Primitive Polynesian Economy, London, G. Routledge.

_, 1946. Malay Fishermen: Their Peasant Economy, London, Kegan Paul, Trench, Trubner.
—, 1951. Elements of Social Organization, London, Watts and Co.

_, 1973. Symbols: Public and Private, Ithaca, Cornell University Press.

—, 1996. Religion: A Humanist Interpretation, London, New York, Routledge.

—, 2001. The Creative Contribution of Indigenous People to their Ethnography, Journal of Polynesian Society 110, 3.

FIRTH Raymond and Mervyn McLeAn, 1990. Tikopia Songs: Poetic and Musical Art of a Polynesian People of the Salomon Islands, London, C.U.P.

Geertz Clifford, 1973. Notes on the Balinese Cockfight, in C. Geertz, The Interpretation of Cultures, New York, Basic Books 2000.

Godelier Maurice, 1982. La Production des Grands Hommes. Pouvoir et domination masculine chez les Baruya de Nouvelle-Guinée, Paris, Fayard.

—, 2004. Les Métamorphoses de la Parenté, Paris, Fayard.

LÉVI-STRAuSs Claude, 1950. Introduction à l'œuvre de Mauss, in Marcel Mauss, Sociologie et anthropologie, Paris, PUF, pp. I-LII.

LyOTARD Jean-François, 1979. La condition postmoderne, Paris, Éditions de Minuit.

Marcus George E., 1998. Ethnography through Thick and Thin, Princeton.

_, 1999. The Uses of Complicity in the Changing Mise-en-Scène of Anthropological Fieldwork, in Sherry Ortner (ed.), The fate of Culture: Geertz and Beyond, Berkeley, The University of California Press, Representations Books 8.

MARSAUdon Françoise, 1998. Les premiers fruits. Parenté, identité sexuelle et pouvoirs en Polynsésie occidentales (Tonga, Wallis et Futuna), Paris, CNRS Éditions, Éditions de la maison des sciences de l'homme.

WAGNER Roy, 1986. Symbols that stand for themselves, Chicago, University of Chicago Press. 